IZA DP No. 10178

Does the Unemployment Invariance Hypothesis Hold for Canada?

Aysit Tansel

Zeynel Abidin Ozdemir

Emre Aksoy

August 2016

Forschungsinstitut zur Zukunft der Arbeit Institute for the Study of Labor 


\title{
Does the Unemployment Invariance Hypothesis Hold for Canada?
}

\author{
Aysit Tansel \\ Middle East Technical University, \\ IZA and ERF \\ Zeynel Abidin Ozdemir \\ Gazi University \\ and ERF \\ Emre Aksoy \\ Kirikkale University \\ Discussion Paper No. 10178 \\ August 2016 \\ IZA \\ P.O. Box 7240 \\ 53072 Bonn \\ Germany \\ Phone: +49-228-3894-0 \\ Fax: +49-228-3894-180 \\ E-mail: iza@iza.org
}

Any opinions expressed here are those of the author(s) and not those of IZA. Research published in this series may include views on policy, but the institute itself takes no institutional policy positions. The IZA research network is committed to the IZA Guiding Principles of Research Integrity.

The Institute for the Study of Labor (IZA) in Bonn is a local and virtual international research center and a place of communication between science, politics and business. IZA is an independent nonprofit organization supported by Deutsche Post Foundation. The center is associated with the University of Bonn and offers a stimulating research environment through its international network, workshops and conferences, data service, project support, research visits and doctoral program. IZA engages in (i) original and internationally competitive research in all fields of labor economics, (ii) development of policy concepts, and (iii) dissemination of research results and concepts to the interested public.

IZA Discussion Papers often represent preliminary work and are circulated to encourage discussion. Citation of such a paper should account for its provisional character. A revised version may be available directly from the author. 
IZA Discussion Paper No. 10178

August 2016

\title{
ABSTRACT \\ Does the Unemployment Invariance Hypothesis Hold for Canada?
}

This article explores the long-run relationship between unemployment rate and labor force participation rate in Canada. The cointegration analysis vindicates the existence of a long-run relationship between these two variables. This finding leads us to doubt the pertinence of the unemployment invariance hypothesis for Canada. This is consistent with the empirical studies for Japan, Sweden and the United States, but contradicts the empirical studies for Australia, Romania and Turkey. There are contradictory studies for the United Kingdom.

JEL Classification: E24, J64, J21

Keywords: unemployment invariance hypothesis, unemployment, labor force participation, cointegration, Canada

Corresponding author:

\author{
Aysit Tansel \\ Department of Economics \\ Middle East Technical University \\ 06531 Ankara \\ Turkey \\ E-mail: atansel@metu.edu.tr
}




\section{Introduction and Literature Review}

This article explores the long-run relationship between unemployment rate and labor force participation rate in Canada. The nature of this relationship has wide implications for the labor market policy, macroeconomic policy as well as macroeconomic theory and modeling in applications. The informational value of the unemployment rate as an indicator of labor market conditions may not be reliable if there are changes in the labor force participation rate over the business cycle. Further, unemployment invariance hypothesis suggests that the labor market adjustments ensure that the long-run unemployment rate is independent of the labor force, capital stock and total factor productivity. The effect of the changes in these can be offset by the labor market adjustments via changes in labor demand, labor supply and wage setting. For instance, an increase in productivity due to technological progress shifts the labor demand curve to the right. According to the unemployment invariance hypothesis the wage setting curve shifts inward by the same amount leaving long-run unemployment unchanged with higher wages. Similar adjustments take place when capital stock increases. However, when there is an increase in the size of the labor force, labor supply shifts to the right. According to the unemployment invariance hypothesis the wage setting curve shifts to the right by the same amount leaving long-run unemployment unchanged with lower wages. These cases are illustrated graphically by Van (2016).

The validity of unemployment invariance hypothesis is a debatable topic among the macroeconomists. Layard, Nickell and Jackman (1991) support it for the United Kingdom while Karanassou and Snower (2004) reject it for the United Kingdom. The latter study develops this result within the framework of an endogenous growth model. Fitoussi at al. (2000) show that long-run unemployment rate is independent of the labor force participation, capital stock and productivity "but only in trendless combinations" in several OECD countries. There are contradictory evidence in more recent studies. Österholm (2010) for Sweden, Emerson (2011) for the United States, Kakinaka and Miyamoto (2012) (for males only) and Liu (2014) (from a regional perspective) for Japan do not find support for unemployment invariance hypothesis. Conversely, Otoiu and Titan (2015) for Romania, Tansel et al. (2016) for Turkey and Van (2016) for Australia do not find a significant long-term relationship between labor force participation and unemployment rates. Hence, unemployment invariance hypothesis is supported in the case of these countries. 
Our objective is to explore the validity of the unemployment invariance hypothesis for the case of Canada. Following questions are asked in this paper. Does unemployment invariance hypothesis hold for Canada? Is the relationship between labor force participation and unemployment similar to that observed in other countries? Do changes in unemployment rates set-off added-worker or discouraged-worker effects? We use monthly data and cointegration analysis. We find that unemployment invariance hypothesis is not supported in the case of Canada.

\section{Methodology and Analysis}

In order to examine the existence of a long-run relationship between unemployment and labor force participation rates we apply the vector error correction (VEC) model to these variables. The VEC model to these variables. The VEC model is a restricted vector autoregresision (VAR) model. The unrestricted VAR model is as follows

$$
y_{t}=\alpha+\sum_{i=1}^{k} A_{i} y_{t-i}+\varepsilon_{t}
$$

where $y_{t}$ is an n-vector of variables to be examined. $\varepsilon_{t}$ is independent, identically distributed random disturbance term. Equation (1) can be rewritten as:

$$
\Delta y_{t}=\alpha+\pi y_{t-1}+\sum_{t=1}^{k-1} r_{i} \Delta y_{t-i}+\varepsilon_{t}
$$

where $\pi=\sum_{i=1}^{k} A_{i}-I$ and $r_{i}=-\sum_{j=i+1}^{k} A_{j}$. Provided that the variable in $y_{t}$ are $I(1), \pi$ has a rank $r$ $(0 \leq r<n)$ where $r$ is the number of cointegrating vectors. We have $\pi=\alpha \beta^{\prime}$ and $\beta^{\prime} y_{t}$ is stationary. $\beta$ is the $n \times r$ matrices of rank $r . \alpha$ is the $r \times n$ of rank $r$ elements of which are adjustment parameters (error-correction terms).

\section{Data}

We use monthly data on the unemployment rate (U) and the labor force participation rate (LFP) for the period January 1976 through December 2015 involving over 460 observations on 40 years. Given that there are differences in the unemployment rates and labor force participation 
rates of men and women we also carry out the analysis for men and women separately. The time series plot of the data are presented in Figure 1 for the aggregate series as well as for the series for men and women.

Figure 1. Labour force participation (LFP) and unemployment (UN) rates, Canada, 1976:M12015:M12.
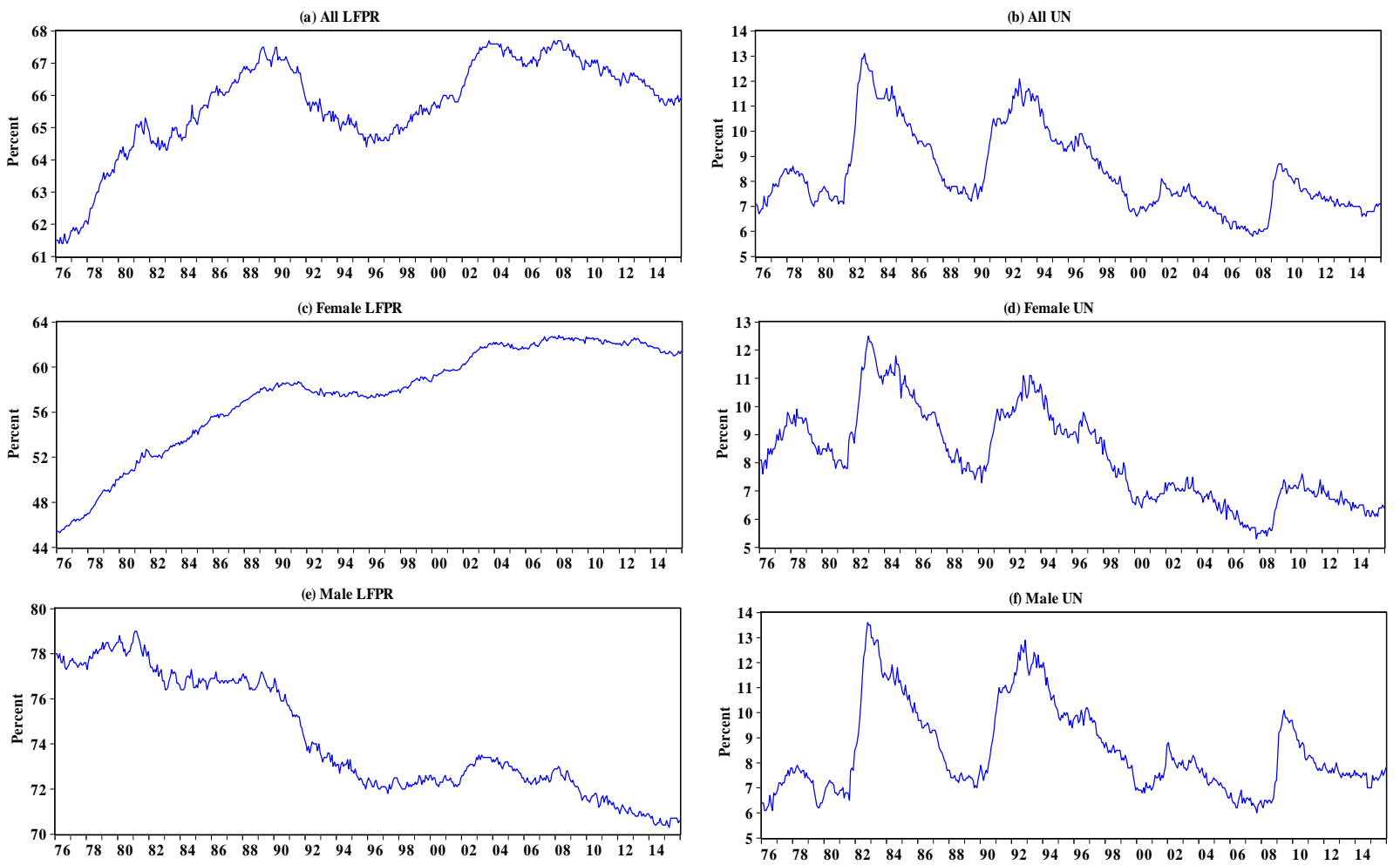

\section{Empirical Analysis}

We first investigate the time series properties of the unemployment rate and the labor force participation rate series. We use Augmented Dickey-Fuller (ADF) unit root test with Generalized Least Square (GLS) detrending due to Elliot, Rothenberg and Stock (1996) as well as the KPPS test of Kwiatkowskyi, Phillips, Schmidt and Shin (1992). ADF-GLS test is a more powerful test which estimates the optimal number of lags to use. The results appear in the Table 1 for the levels and first differences of the series. ADF-GLS tests indicate that the null hypothesis of non-stationarity cannot be rejected at 5 percent level of significance for all the series. The KPSS test results suggest that the null hypothesis of stationarity is rejected for all of the series at 5 percent level. These results indicate that all of the series are non-stationary ie have a unit root. Further testing of the first differences of the series indicate the following. With the ADF-GLS test the null hypotheses of nonstationarity is rejected for all of the series at 5 percent level of significance. With the KPSS test the null hypothesis of stationarity is not rejected at 5 
percent level of significance for all series. These results indicate that the first difference series are stationary. Based on these tests, we conclude that all of the series are integrated of order one.

Table 1. Unit root tests for the unemployment and labour force participation rates, Canada, 1976:M1-2015:M12.

\begin{tabular}{lclll}
\hline \multicolumn{2}{c}{ Level } & \multicolumn{2}{c}{ First Differences } \\
\hline Series & ADF-GLS & & ADF-GLS & KPSS \\
\hline Labour force participation rate & KPSS $^{\mathrm{b}}$ & & \\
\hline \multicolumn{1}{l}{ All } & $0.41(1)$ & $1.37^{*}$ & $-26.69^{*}(0)$ & 0.34 \\
\hline Males & $1.32(1)$ & $2.48^{*}$ & $-26.28^{*}(0)$ & 0.09 \\
\hline Females & $1.65(5)$ & $2.38^{*}$ & $-7.05^{*}(4)$ & 0.45 \\
\hline Unemployment rate & & & & 0.08 \\
\hline All & $-1.73(3)$ & $0.89^{*}$ & $-4.97^{*}(4)$ & 0.08 \\
\hline Males & $-1.59(3)$ & $0.68^{*}$ & $-9.10^{*}(2)$ & 0.09 \\
\hline Females & $-1.16(3)$ & $1.74^{*}$ & $-25.26^{*}(0)$ & \\
\hline
\end{tabular}

Notes: * indicates significance at the 5 percent level. The lag lengths (given in parentheses) are established using the Schwarz Information Criteria.

aTest allows for a constant; one-sided test of the null hypothesis that the variable has a unit root; 1,5 and 10 percent critical values are equal to $-2.56,-1.94$ and -1.61 , respectively.

${ }^{\mathrm{b}}$ Test allows for a constant; one-sided test of the null hypothesis that the variable is stationary; 1 , 5 and 10 percent critical values are equal to $0.73,0.46$ and 0.34 , respectively.

After establishing that the unemployment rate and the labor force participation rate are unit root processes we next test if there is a long-run relationship between them within a cointegration framework. Johansen's methodology (1988:1991) provide two complementary cointegration test statistics. They are the trace and the maximum-eigenvalue tests which are reported in Table 2.

Table 2. Multivariate Cointegration test results between the labour force participation rate and unemployment rate, Canada, 1976:M1-2015:M12.

\begin{tabular}{ccccccc}
\hline & \multicolumn{2}{c}{ All } & \multicolumn{2}{c}{ Males } & \multicolumn{2}{c}{ Females } \\
\hline Hypothesis & $\begin{array}{c}\text { Trace } \\
\text { statistics }^{\text {a }}\end{array}$ & $\begin{array}{c}\text { Maximum- } \\
\text { eigenvalue }^{\mathrm{b}}\end{array}$ & $\begin{array}{c}\text { Trace } \\
\text { statistics }\end{array}$ & $\begin{array}{c}\text { Maximum- } \\
\text { eigenvalue }\end{array}$ & $\begin{array}{c}\text { Trace } \\
\text { Statistics }\end{array}$ & $\begin{array}{c}\text { Maximum- } \\
\text { eigenvalue }\end{array}$ \\
\hline$r=0$ & $20.431^{*}$ & $15.541^{*}$ & $26.393^{*}$ & $26.205^{*}$ & $38.139^{*}$ & $33.679^{*}$ \\
$r \leq 1$ & 4.889 & 4.889 & 0.187 & 0.187 & 4.460 & 4.460 \\
\hline
\end{tabular}

Notes: Lag lengths in the VAR (in levels) are selected using the AIC.

*indicates significance at 5 percent level of significance.

a One-sided test of the null hypothesis that the variables are not cointegrated; 5 percent Osterwald-Lenum (1992) critical value is equal to 15.41 for the null hypothesis.

b One-sided test of the null hypothesis that the variables are not cointegrated; 5 percent Osterwald-Lenum (1992) critical value is equal to 14.07 for the null hypothesis. 
Both the trace and the maximum-eigenvalue tests indicate that the null hypothesis of nocointegration is rejected at 5 percent level and there is one and only one cointegrating vector in all cases considered. These results are robust since the two cointegration tests are in agreement as it is suggested by Hjalmarsson and Österholm (2010). This finding suggests that there is a long-run relationship between the unemployment and labor force participation rates for the cases of aggregate series, and the series for men and women. Hjalmarsson and Österholm (2010) further warn that the trace and the maximum eigenvalue tests have size distortions when the series have near unit roots. In such cases they suggest further testing of the two restrictions on the cointegrating vector $(\beta)$. They are $\beta=\left(\begin{array}{ll}1 & 0\end{array}\right)^{\prime}$ and $\beta=\left(\begin{array}{ll}0 & 1\end{array}\right)^{\prime}$. If they are both rejected then the cointegration holds. If both of them or either of them cannot be rejected then cointegration does not hold and it may be due to a single stationary variable. In order to allow for the possibility of near unit roots we further test the above restrictions on the cointegrating vectors. The results of likelihood ratio tests shown in Table 4 indicate that both of the restrictions are strongly rejected implying that co-integration holds. Therefore, cointegration is supported and a long-run relationship between unemployment rates and labor force participation rates exits in all cases considered. The cointegrating vectors suggest the added-worker effect for men and discouragedworker effect for women.

Table 3. Estimated cointegrating vector, Canada, 1976:M1-2015:M12.

\begin{tabular}{lccc}
\hline & All & Male & Female \\
\hline LFPR & 1.000 & 1.000 & 1.000 \\
UN & 0.616 & -3.903 & 1.074 \\
& $(0.230)$ & $(0.788)$ & $(0.363)$ \\
\hline
\end{tabular}

Note: Standard errors are reported in parentheses.

Finally we consider the short-run dynamics in the relationship between unemployment rate and the labor force participation rate. We test the following restrictions on the error-

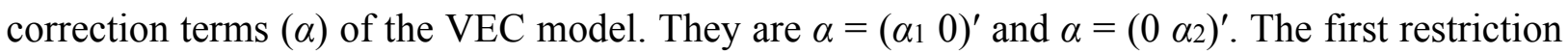
suggests that the labor force participation rate does error correct but the unemployment rate does not while the second restriction implies the opposite. The results of the likelihood ratio tests are shown at the bottom part of the Table 4. Both of the restrictions are strongly rejected in all cases. These results confirm that both the labor force participation rates and the unemployment rates are weakly exogenous. 
Table 4. Tests of restrictions in cointegrated VAR in Canada for the 1976:M1-2015:M12 period.

\begin{tabular}{|c|c|c|c|}
\hline Restriction & All & Male & Female \\
\hline$\beta=\left(\begin{array}{ll}1 & 0\end{array}\right)^{\prime}$ & $\begin{array}{c}4.711 \\
(0.029)\end{array}$ & $\begin{array}{c}24.259 \\
(0.000001)\end{array}$ & $\begin{array}{c}4.782 \\
(0.028)\end{array}$ \\
\hline$\beta=\left(\begin{array}{ll}0 & 1\end{array}\right)^{\prime}$ & $\begin{array}{l}10.506 \\
(0.001)\end{array}$ & $\begin{array}{c}3.843 \\
(0.049)\end{array}$ & $\begin{array}{l}27.486 \\
(0.000)\end{array}$ \\
\hline$\alpha=\left(\begin{array}{ll}\alpha_{1} & 0\end{array}\right)^{\prime}$ & $\begin{array}{c}7.587 \\
(0.005)\end{array}$ & $\begin{array}{c}25.178 \\
(0.000001)\end{array}$ & $\begin{array}{c}12.943 \\
(0.0003)\end{array}$ \\
\hline$\alpha=\left(\begin{array}{ll}0 & \alpha_{2}\end{array}\right)^{\prime}$ & $\begin{array}{c}9.883 \\
(0.001) \\
\end{array}$ & $\begin{array}{c}7.458 \\
(0.006) \\
\end{array}$ & $\begin{array}{l}27.339 \\
(0.000) \\
\end{array}$ \\
\hline
\end{tabular}

Notes: The values reported are the $p$-values of the likelihood ratio test for the restrictions.

\section{Conclusion}

This paper provides evidence that there is a long-run equilibrium relationship between labor force participation rate and unemployment rate in Canada. This result holds also when gender specific data are used. Therefore, we conclude that unemployment invariance hypothesis is not supported in Canada. This result is similar to the Karanassou and Snower (2004) for the United Kingdom, Österholm (2010) for Sweden, Emerson (2011) for the United States and Kakinaka and Miyamoto (2012) for Japan (male sample) where unemployment invariance hypothesis is not supported. However these studies contradict Layard, Nickell and Jackman (1991) in the United Kingdom, Tansel et al. (2016) in Turkey, Otoiu and Titan (2015) in Romania and Van (2016) Australia where there is no long-run equilibrium relation between labor force participates and unemployment rates and therefore unemployment invariance hypothesis is supported. We further find evidence for added-worker effect for men and discouraged-worker effect for women in Canada. This is contrary to what is found in the United States where there is evidence of discouraged worker effect especially for men. The lack of support for the unemployment invariance hypotheses implies that changes in the labor force participation rate which may be due to aging population will affect the unemployment rate in the long-run. Similarly, policies of early retirement or constraints on working time which reduce effective working age population may influence the long-run unemployment rate. Thus, unemployment rate is influenced by the evolution of labor force participation rate. Further, policies which improve technology, encourage investment, capital accumulation or research and development will also affect the unemployment rate in the long-run. The findings in this paper will contribute to our understanding of the functioning of the labor market in Canada. 
The diversity of results with respect to different countries should be investigated. It is not clear what may be the reasons for this diversity. It may be due to the differences in the factors that influence labor market adjustment. Labor market institutions may be one such factor that influence the adjustment mechanisms in different labor markets.

\section{References}

Elliot, G., Rothenberg, T. J. and Stock, J. H. (1996) "Efficient tests for an autoregressive unit root",Econometrica, vol. 64, pp. 813-36.

Emerson, J. (2011) "Unemployment and labor force participation in the United States", Economics Letters, vol. 111, pp. 203-6.

Gustavsson, M. and Österholm, P. (2006) "The informational value of unemployment statistics: a note on the time series properties of participation rates", Economics Letters, vol. 92, pp.428-433.

Hjalmarsson, E., and P. Österholm. (2010) "Testing for Cointegration Using the Johansen Methodology When Variables are Near-Integrated: size distortions and partial remedies", Empirical Economics, vol.39, pp.51-76.

Johansen, S. (1988) "Statistical analysis of cointegration vectors", Journal of Economic Dynamics and Control, vol. 12, pp. 231-54.

Johansen, S. (1991) "Estimation and hypothesis testing of cointegration vectors in Gaussian vector autoregressive models", Econometrica, vol. 59, pp. 1551-80.

Kakinaka, M. and Miyamoto, H. (2012) "Unemployment and labour force participation in Japan", Applied Economics Letters, vol. 19, pp. 1,039-43.

Karanassou, M. and Snower, D. J. (2004) "Unemployment invariance", German Economic Review, vol. 5, pp. 297-317.

Kwiatkowski, D., Phillips, P. C., Schmidt, P. and Shin, Y. (1992) "Testing the null hypothesis of stationarity against the alternative of a unit root: How sure are we that economic time series have a unit root?", Journal of Econometrics, vol. 54, pp. 159-78.

Layard, R., Nickell, S. and Jackman, R. (1991) Unemployment: Macroeconomic Performance and the Labour Market, Oxford University Press, Oxford.

Oţoiu, A. and Țiţan, E. (2016) "Does the unemployment invariance hypothesis hold for Romania?", Applied Economics Letters, vol.23(12), pp. 884-887.

Osterholm, P. (2010) "Unemployment and labour-force participation in Sweden", Economics Letters, vol. 106, pp. 205-8.

Tansel, A., Ozdemir, Z. A., and Aksoy, E. (2016) "Unemployment and labour force participation in Turkey", Applied Economics Letters, vol.23(3), pp.184-187.

Van, P. N. (2016) "Examining the unemployment invariance hypothesis: The case of Australia", The Australian Economic Review, vol. 49, no. 1, pp. 54-8. 